\title{
An analysis based on rotifer indices of the effects of water and sewage management on water quality in the system of interconnected glacial lakes
}

\author{
Jolanta Ejsmont-Karabin \\ Department of Hydrobiology, Institute of Biology, University of Białystok, Świerkowa 20 B, 15-950 Białystok, Poland, \\ e-mail: jolanta@onet.pl
}

\begin{abstract}
The aim of the study was the long-term observation of changes in the trophic status of the Great Masurian Lakes versus changes in the management of lakes' watershed. The Great Masurian Lakes (GML), a system of interconnected glacial lakes, were, until the 80 s, receivers of untreated and partially treated sewage from cities and diffuse sources, particularly in the tourist season. In the 90s, state farm areas turned into fallow land, which reduced the input of nutrients from diffuse sources. In the late 90 s municipal sewage plants began to be systematically built in cities and the larger villages of the region. An analysis of changes in the trophic status of the GML hydro-system during the period of 35 years was based on rotifer indices of lake trophy. Results of the analysis show that in 1976 lakes in the northern and southern part of the GML system were mesotrophic or meso-eutrophic, while in the central part, in the triangle formed by three cities, the beginning of eutrophication was observed. After several years of increased inflow of nutrients due to the impact of tourism, a marked increase in the trophy of lakes was noticed in the central part of the system. In the 90s, after the collapse of large-scale agriculture and the installation of modern sewage treatment plants, the trophic status of nearly all lakes in the central and southern parts of the system ranged between meso-eutrophy and low eutrophy. The exceptions were Lake Nidzkie, whose trophy increased and Lake Niegocin, which became mesotrophic. Changes in the trophic status of the studied lakes indicate high sensitivity of the GML system to anthropogenic changes in their watershed.
\end{abstract}

Key words: Rotifera, monitoring, eutrophication, self-purification, bioindication

\section{Introduction}

Eutrophication of lakes, accelerated as a result of the increased supply of nutrients to lake waters, still represents one of the most important threats to the quality of surface waters. Among the procedures undertaken to prevent this phenomenon, the dominant role is played by reduction of nutrient loading from the watershed, which entails, first of all, installing sewage treatment plants (Carey and Migliaccio 2009).

Since the demonstration by Einsele (1938) and Mortimer (1942), that in the presence of oxygen sediments accumulate phosphorus by binding it with iron, it is believed that by providing sufficient oxygen to the hypolimnion we could stop or even reverse the process of eutrophication. Based on this theory, a technology of aeration of hypolimnetic layers has been developed since the 1980s. It was widely accepted as a rela- tively simple and inexpensive way to lower the trophic status of heavily eutrophicated, deep lakes. However, the long-term results of these procedures vary widely. Some of the lakes in this way gradually decreased their trophic status until mesotrophy (eg. Lake Krupunder according to Jaeger 1994). In other lakes the increase in oxygen concentration in the hypolimnion only slightly affected the density and composition of phytoplankton (Ashley 1988; Soltero et al. 1994; Grochowska and Gawrońska 2004). Lean et al. (1986) believed that only half of the cases using this treatment type were a success. Nevertheless, Ashley $(1988,2000)$ predicted that in the twenty-first century oxygenation of the hypolimnion would become a standard practice in order to restore water quality in eutrophic lakes.

Meanwhile lakes with relatively low nutrient loading may be subject to the process of self-purification, as some of the nutrients are continuously depos- 
ited in sediments. Can we then assume that reducing nutrient inflows from the catchment area will lead to lower trophy of lakes as a result of phosphorus precipitation with trypton? The answer to this question is not clear. Cullen and Forsberg (1988) in their study received three types of lake response to reduced phosphorus load: a marked decline in chlorophyll concentration, a weak effect or a complete lack thereof. Should we expect that a reduction in nutrient load in the system of interconnected lakes can have immediate effect illustrated with changes in the lake trophy? How quickly does the lake ecosystem respond to the decrease in the rate of nutrient loading? The aim of this study is to answer these questions by long-term observation of changes in the trophic status of the Great Masurian Lakes versus changes in the management of the lakes' watershed.

\section{Material and methods}

The results presented in this paper are based on data collected in the years 1976, 1985, 1988, 1996, 2005 and 2011 from 21 lakes of the Great Masurian Lakes' system (NW, Poland). The lakes are a part of a complex of lakes, interconnected naturally or artificially by canals. They constitute the largest complex of lakes in Poland, covering about $10 \%$ of the total area of Polish lakes. Polymictic lakes are located mainly in the southern part of the system. Morphometric and trophic characteristics of these lakes are presented by Kufel (1999).

The system is divided into two watersheds, and the water divide line is located close to the town of Giżycko. Main small towns (Giżycko, Mikołajki and Ryn) and tourist resorts are located on deep lakes in the central part of the GML system. They are a main source of pollution and nutrient loading to the lakes.

Rotifer samples were taken using a $5 \mathrm{~L}$ Bernatowicz sampler at the deepest place in the lake at $1 \mathrm{~m}$ intervals from the surface to the bottom of the epilimnion layer, and then samples were pooled together and filtered through a plankton net. The mesh size of the net was $30 \mu \mathrm{m}$. Samples were taken once a year, during the summer stagnation.

The following indices were used with the aim of assessing the trophic state of the studied lakes (Ejsmont-Karabin 2012): (1) rotifer numbers; (2) total biomass of rotifer community; (3) percentage of bacterivores in total rotifer numbers; (4) ratio of biomass to numbers; (5) percentage of the tecta form in the population of Keratella cochlearis; (6) contribution of species which indicate high trophy in the indicatory group's numbers. The standard wet weights according to Ejsmont-Karabin (1998) were used as individual body-weights of rotifers.

\section{Results and discussion}

In the 1970s the Great Masurian Lakes were very popular among tourists, but poorly developed infrastructure did not allow very intensive use of this system of lakes by boaters and campers. Nevertheless, it was already possible to notice the first signs of accelerated eutrophication of the lakes. According to Soszka and Cydzik (1979) in 1976/1977 only lakes Mamry and Śniardwy were in class I of water quality. The relatively good water quality characterized Lake Tałtowisko, while class III water quality was found in Lake Niegocin. In lakes Mikołajskie, Bełdany, Tałty and Ryńskie significant deficits in oxygen were reported.

Trophic status indicators calculated on the basis of the structure of rotifer communities indicated, however, that the lakes at the north and south ends of the GML system still remained mesotrophic and meso-eutrophic, and the first signs of increasing eutrophy could be seen in the lakes of the central part of the system, i.e. the lakes enriched with nutrients derived from point sources (Table 1) located in and around the cities Giżycko, Tałty and Ryn (Fig. 1). Lakes Mikołajskie, Jagodne and Ryńskie, on the basis of their rotifer zooplankton, could be defined as eutrophic.

In the 1980s tourism was markedly intensified and the lakes were fed with nutrients delivered from both tourist resorts and large-scale farms surrounding the GML. At the same time the unfavourable financial situation of the country did not allow modernization or construction of modern sewage treatment plants. Excessive loading of nutrients to lakes in the so-called "tourist triangle", i.e. the lakes situated in the triangle of the largest cities of the region - Giżycko, Ryn and Tałtowisko - was manifested in the growth of their trophy (Table 1, Fig. 1 see data for the year 1988). As a result, rotifer zooplankton in Lakes Niegocin, TałtyRyn, Mikołajskie and Bełdany clearly indicated a very advanced eutrophication of the lakes (i.e. close to hypertrophy).

In the years 1994-2000, as a part of the "MASTERPLAN for the Great Masurian Lakes", 18 waste purification plants and many kilometres of a sanitary sewage network were built or modernized. Since 1996, 
Table 1. Mean values of rotifer indices of lake trophy for some lakes of the Great Masurian Lakes system; explanation: values of the index below 35 indicate oligotrophy, from 35 to 40 low mesotrophy, 40-45 - high mesotrophy, 45-50 - low meso-eutrophy, 50-55 - high mesoeutrophy, 55-60 - low eutrophy, 60-65 - high eutrophy, above 65 - hypertrophy

\begin{tabular}{|c|c|c|c|c|c|}
\hline \multirow{2}{*}{ Lake } & \multicolumn{5}{|c|}{ Years } \\
\hline & 1976 & $1985-1988$ & 1996 & 2005 & 2011 \\
\hline Bełdany & $51.4 \pm 3.8$ & $60.7 \pm 2.9$ & $57.6 \pm 1.3$ & $52.4 \pm 2.6$ & $57.3 \pm 2.6$ \\
\hline Białoławki & - & $56.2 \pm 3.3$ & $53.7 \pm 2.3$ & $50.0 \pm 2.7$ & - \\
\hline Boczne & $52.2 \pm 8.1$ & $53.1 \pm 4.8$ & $58.1 \pm 5.2$ & $50.5 \pm 7.3$ & $52.6 \pm 4.3$ \\
\hline Dargin & $45.8 \pm 3.8$ & $38.6 \pm 8.7$ & $44.9 \pm 8.6$ & $46.3 \pm 2.3$ & $50.8 \pm 4.3$ \\
\hline Dobskie & $48.1 \pm 9.0$ & - & $44.1 \pm 4.5$ & - & - \\
\hline Guzianka Wlk. & $54.0 \pm 2.9$ & - & - & $57.6 \pm 2.5$ & - \\
\hline Jagodne & $58.4 \pm 4.2$ & $60.7 \pm 3.3$ & $66.5 \pm 2.4$ & $58.2 \pm 3.5$ & $48.8 \pm 7.8$ \\
\hline Kirsajty & $49.9 \pm 5.0$ & $44.6 \pm 4.2$ & - & - & - \\
\hline Kisajno & $47.7 \pm 4.3$ & $43.1 \pm 2.4$ & $51.0 \pm 2.9$ & $50.2 \pm 2.9$ & $52.0 \pm 1.7$ \\
\hline Łabab & $42.0 \pm 5.4$ & - & - & $49.9 \pm 2.5$ & \\
\hline Łuknajno & - & $52.7 \pm 1.6$ & $55.8 \pm 6.4$ & - & - \\
\hline Mamry & $47.6 \pm 9.4$ & $51.0 \pm 3.4$ & $47.8 \pm 4.1$ & $50.7 \pm 1.8$ & $51.6 \pm 4.1$ \\
\hline Mikołajskie & $56.2 \pm 3.9$ & $62.2 \pm 4.5$ & $60.4 \pm 1.8$ & $51.5 \pm 2.2$ & $53.2 \pm 3.4$ \\
\hline Nidzkie & $51.8 \pm 4.0$ & $55.3 \pm 3.8$ & $53.4 \pm 2.2$ & $62.2 \pm 1.8$ & - \\
\hline Niegocin & $53.1 \pm 6.1$ & $64.9 \pm 2.9$ & $56.5 \pm 4.6$ & $49.9 \pm 9.5$ & $48.0 \pm 4.1$ \\
\hline Przystań & - & $49.9 \pm 3.9$ & $46.8 \pm 4.1$ & - & $51.5 \pm 3.8$ \\
\hline Ryńskie & $56.3 \pm 5.1$ & $62.3 \pm 4.3$ & $62.9 \pm 4.6$ & $57.9 \pm 2.9$ & $53.7 \pm 1.3$ \\
\hline Szymon & $59.0 \pm 4.9$ & - & $63.8 \pm 4.4$ & - & $53.6 \pm 1.7$ \\
\hline Śniardwy & $50.4 \pm 7.0$ & $52.6 \pm 3.1$ & $51.0 \pm 6.4$ & $49.0 \pm 4.1$ & $57.8 \pm 3.0$ \\
\hline Święcajty & $50.6 \pm 3.1$ & $47.0 \pm 5.4$ & $58.5 \pm 1.7$ & $54.9 \pm 5.7$ & - \\
\hline Tałtowisko & $57.0 \pm 4.2$ & $55.1 \pm 3.8$ & $65.5 \pm 2.4$ & $59.9 \pm 2.2$ & $49.8 \pm 5.8$ \\
\hline Talty & $53.1 \pm 3.8$ & $62.6 \pm 6.3$ & $58.0 \pm 2.0$ & $56.3 \pm 3.8$ & $55.7 \pm 3.7$ \\
\hline Tuchlin & - & $57.1 \pm 5.9$ & $61.5 \pm 2.4$ & $56.9 \pm 5.0$ & - \\
\hline Tyrkło & $61.0 \pm 3.4$ & - & $60.8 \pm 7.4$ & $57.7 \pm 5.3$ & - \\
\hline
\end{tabular}

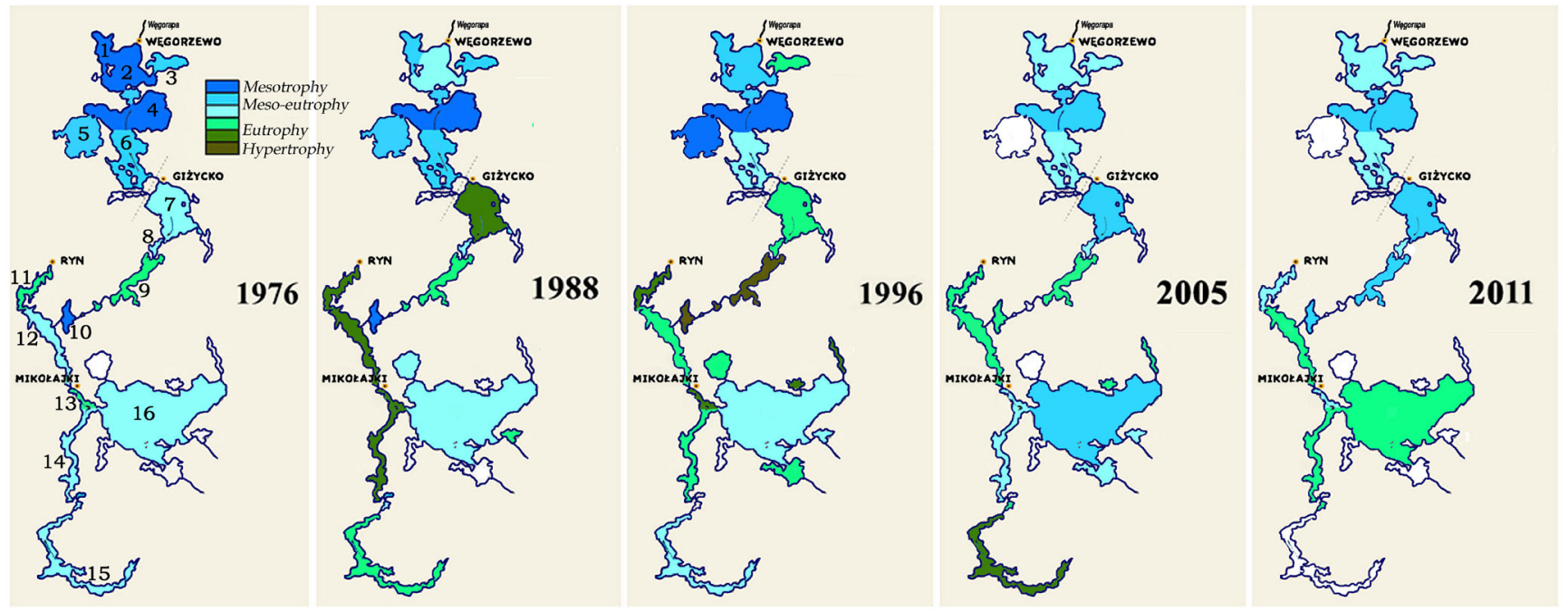

Fig. 1. Trophic status of the Great Masurian Lakes in the years 1976, 1988, 1996, 2005 and 2011, based on rotifer indices of lake trophy. Lakes: 1,2 - Mamry; 3 - Święcajty; 4 - Dargin; 5 - Dobskie; 6 - Jisajno; 7 - Niegocin; 8 - Boczne; 9 - Jagodne; 10 - Tałtowisko; 11 Ruńskie; 12 - Tałty; 13 - Mikołajskie; 14 - Bełdany; 15 - Nidzkie; 16 - Śniardwy 
the modernized waste treatment plant has worked, collecting sewage from Giżycko and its surroundings. Thus the first signs of improvement of water quality in Lake Niegocin can perhaps be attributed to the impact of the wastewater treatment plant. However, the transfer of the nutrient load into the southern part of the GML system resulted in a sharp increase in the trophic state of Lakes Jagodne and Tałtowisko (Fig. 1, see data for the year 1996). At the same time the trophic status of the other lakes located in the central part of the system did not change (Lake Ryn and Mikołajskie) or showed a slight decrease (Lake Talty).

Much clearer signs of decline in the trophic state of lakes in the central part of the GML system were seen in 2005, a couple of years after treatment plants began running in all major urban areas of the region. Significant reduction in the trophic status of lakes located in the "Masurian triangle" was, however, accompanied by a sharp increase in the trophic status of the previously meso-eutrophic Lake Nidzkie. This phenomenon is particularly painful because the lake is a nature reserve.

In the year 2011 two phenomena were noticed which seemed to be dangerous to the water quality in the southern part of the system: (1) further decline in the trophic state of the Great Masurian lakes was stopped, and (2) there was a marked increase in the trophic state of Lake Śniardwy. The former was probably the result of high phosphorus loading with posttreatment sewage, as even after chemical precipitation of phosphorus, waters discharged from the sewage treatment plants directly into a lake may exceed 10 to 100 times the natural concentrations of phosphorus. The second phenomenon is probably related to the inflow of $\mathrm{P}$ accumulated in the "triangle" lakes to the southern part of the system. As a result, Lake Sniardwy, not yet undergoing eutrophication, quickly changed its status because of receiving nutrients from lakes located in the central part of the system.

The three periods mentioned above, i.e. rapid eutrophication up to 1995, then ten years of "oligotrophication", and eutrophication of lakes in the southern part of the GML system, have been described by Siuda et al. (2013). The authors pointed out particularly the important role nutrients contributed with water currents from the central part of the system play in the eutrophication of the southern part of the GML system.
The history of changes in the trophic status of lakes along with changes in their catchment area indicates the high sensitivity of the Great Masurian Lakes' system to changes in nutrient loading. Thus, reducing the input of nutrients to lakes we can decrease their trophy much faster than it was previously believed. However, the oligotrophication of lakes proceeds up to a nutrient level at which nutrient loading with treated sewage starts to fertilize the lakes again.

The increased Secchi depth, decreased chlorophyll concentration and reduced phytoplankton biomass were observed in Danish lakes after reduction in nutrient loading after launching the Danish National Aquatic Monitoring and Assessment Programme (Anderson et al. 2005; Kronvarg et al. 2005). On the other hand, a model developed to predict the rate of natural purification of the eutrophic Lake Donghu, indicated that restoration of the lake needs fifty years or more (Jiang and Shen 2006). The discrepancies in ecosystem response to reduced nutrient inputs may be explained by the very complicated nature of the processes supporting the self-purification of lakes, such as dilution of pollutants, their absorption of organic particles, chemical oxidation, uptake of nutrients by organisms and many others.

\section{References}

Anderson N.J., Jeppesen E., Sondergaard M., 2005, Ecological effects of reduced nutrient loading (oligotrophication) on lakes: an introduction, Freshwater Biol. 50: 1589-1593

Ashley K.I., 1988, Hypolimnetic aeration research in British Columbia, Verh. Int. Ver. Limnol. 23: 215-219.

Ashley K.I., 2000, Recent advances in hypolimnetic aeration design, Verh. Int. Ver. Limnol. 27: 2256-2260.

Carey R.O, Migliaccio K.W., 2009, Contribution of wastewater treatment plant effluents to nutrient dynamics in aquatic systems: a review, Environ. Manage. 44: 205-217. Cullen P., Forsberg C., 1988, Experiences with reducing point sources of phosphorus to lakes, Hydrobiologia 170: 321-336.

Einsele W., 1938, Uber chemische und kolloidchemische Vorgange in Eisen-Phosphat-Systemen unter limnochemischen und limnogeologischen Gesichtspunkten, Arch. Hydrobiol. 33: 361-387.

Ejsmont-Karabin J., 1998, Empirical equations for biomass calculation of planktonic rotifers, Pol. Arch. Hydrobiol. 45: 513-522.

Ejsmont-Karabin J., 2012, The usefulness of zooplankton as lake ecosystem indicators: rotifer trophic state index, Pol. J. Ecol. 60: 339-350. 
Grochowska, J., Gawrońska H., 2004, Restoration effectiveness of a degraded lake using multi-year artificial aeration, Pol. J. Environ. Stud. 13: 671-681.

Jaeger D., 1994, Effects of hypolimnetic water aeration and iron-phosphate precipitation on the trophic level of Lake Krupunder, Hydrobiologia 275/276: 433-444.

Jiang J.-G., Shen Y.-F., 2006, Estimation of the natural purification rate of a eutrophic lake after pollutant removal. Ecol. Engin. 28: 166-173.

Kronvag B., Jeppesen E., Conley D.J., Sondergaard M., Larsen S.E., Ovesen N.B., Carstensen J., 2005, Nutrient pressures and ecological responses to nutrient loading reductions in Danish streams, lakes and coastal waters, J. Hydrol. 304: 274-288.

Kufel L.,1999, Dimictic versus polymictic masurian lakes: similarities and differences in chlorophyll-nutrient-SD relationships, Hydrobiologia 408/409: 389-394.

Lean D.R.S., McQueen D.J., Story V.A., 1986, Phosphate transport during hypolimnetic aeration, Arch. Hydrobiol. 108: 269-280.

Mortimer C. H., 1942, The exchange of dissolved substances between mud and water in lakes (Part II), J. Ecol. 30: 147-201.
Siuda W., Kaliński T., Kauppinen E., Chróst R. 2013, Eutrofizacja południowej części kompleksu Wielkich Jezior Mazurskich w latach 1977-2011. Przyczyny, mechanizmy i skutki (Eutrophication of the southern part of the Great Masurian Lakes complex in the years 19772011. Causes, mechanisms and effects). Retrieved from http://www.zemuw.pl/pl/files/docs/JM_Eutrofizacja_ jezior_mazurskich.pdf (in Polish).

Soltero R.A., Sexton L.M., Ashley K.I., McKee K.O, 1994, Partial and full lift hypolimnetic aeration of Medical lake, WA to improve water quality, Water Res. 28: 2297 2308.

Soszka H., Cydzik D., 1979, Uwagi o stanie czystości wód Wielkich Jezior Mazurskich w świetle obowiązujących przepisów prawnych (Some remarks on water quality of the Great Masurian Lakes according to obligatory legislation), Wiad. Ekol. 25: 53-56 (in Polish, English summary). 